\section{TERRITORIALIDADES DO oeste de são paUlo: transformações e interpretações} Territorialities of The São Paulo West: transformations and interpretations

\section{RESUMO}

Este artigo propõe uma reflexão em torno da formação territorial do novo oeste de São Paulo no final do século XIX e início do século $X X$, buscando identificar algumas estruturas dominantes, tais como os processos de criação de cidades, de instalação de redes ferroviárias e organização da ocupação. Essas estruturas foram interpretadas pelos atores históricos, em diversos momentos do passado, por meio de representações sociais dominantes do território, atribuidoras de sentido naturalizado e imanente à região e definidora dos agentes decisivos para a sua constituição.

Palavras-chave: São Paulo; Território; Oeste; Cidade; Ferrovia.

\section{Célio José}

\section{LOSNAK}

Universidade Estadual Paulista Júlio de Mesquita Filho - UNESP/Bauru

losnak@faac.unesp.br

\begin{abstract}
This paper reflects on the territorial formation of the new west of São Paulo at the end of XIX century and beginning of XX century, seeking to identify some dominant structures such as the process of the town creation, building of railway networks and organization of the settlements. These structures were interpreted by historical agents, during various periods in the past, by means of dominant social representations of the territory, attributed to naturalized meaning and immanent to the region and defining of crucial agents for its constitution.
\end{abstract}

Keywords: São Paulo; Territory, West, City, Railway. 


\section{Introdução}

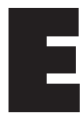

ste texto parte de algumas reflexões para pensar o objeto de pesquisa de um grupo multidisciplinar, formado por arquitetos e historiadores, que objetivava coletar documentação e problematizar a circulação de saberes e a configuração e reconfiguração de cidades do atual oeste de São Paulo. ${ }^{1}$ Buscando elucidar os liames e amarras entre objeto e pesquisadores, da delimitação espacial como pressuposto de lógicas internas próprias ao objeto que, por sua vez, é resultado da formação histórica da região, apontamos dinâmicas temporais constituintes dos espaços como instâncias de saberes, representações e práticas sociais, identifica movimentos dominantes de consolidação de memórias constituintes da materialidade e dos sentidos atribuídos à passagem da natureza à urbanização, delineia a presença de homogeneidades e heterogeneidades nesse processo de ocupação e de inteligibilidades sobre ele. Para tanto, elaboramos uma abordagem panorâmica, apresentando sobrevoo pelo novo oeste durante o final do século XIX e primeiras décadas do XX, detalhando a área delimitada pela abrangência da Estrada de Ferro Noroeste do Brasil.

Um problema inicial ao tratar da área denominada de "Oeste de São Paulo" é que esse conceito não é unânime, há imprecisão para definir quais são os limites, pois os critérios de delimitação e a temporalidade variam. As referências de direção definidas pelos pontos cardeais se constituem em premissa importante para diferenciar lugares e ordenar o espaço, entretanto são elaboradas historicamente à medida que a formação urbana e rural se expande e se transforma no decorrer dos séculos XIX e XX em São Paulo e os agentes sociais (engenheiros, botânicos, geógrafos, historiadores, memorialistas, jornalistas, sociólogos, escritores e moradores) contribuem para uma nova categorização do oeste.

A segunda questão é que área e região têm sido utilizadas como sinônimas para referir-se a um aspecto do objeto de pesquisa: uma base geográfica física do estado de São Paulo em processo de mudança, revelando homogeneidades e heterogeneidades em conformação territorial e temporal específicas, por exemplo: implantação de ferrovias e da cafeicultura, intensificação do comércio de terras e a formação de cidades. Nessa estratégia de definirmos um tema e um objeto recortados espacialmente, com a indicação de que se forma uma região, estamos no âmbito do problema apontado por Bourdieu (2005). Para ele, a definição de região liga-se ao jogo político, ao poder de classificar, de definir, de unir e separar, de dar legitimidade por meio de estratégias de manipulação simbólica. Ao estudarmos a formação das cidades do novo oeste de São Paulo, estaríamos reforçando uma determinada representação socioespacial, tratada pelos agentes sociais do início do século XX e reproduzida por intelectuais e profissionais do periodo e posteriores a ele. Segundo a perspectiva de Bourdieu, correríamos o risco de manter a estratégia de criação da autoridade e de sua legitimação a partir da definição de um objeto, a região, e da produção de um saber que seria justificado com base na própria constituição desse objeto. Como resposta 
a essa armadilha, propomos abordar alguns importantes recortes do processo histórico de tessitura do território e de suas representações sociais (CHARTIER, 1990).

As categorias espaço e território estão em jogo na problematização, a trama conceitual em torno dessas categorias é tarefa hercúlea, e não é o objetivo aqui discutirmos a bibliografia produzida. Optamos por uma via instrumental, aclarar preliminarmente os conceitos para precisar o texto e delinear a análise de nosso objeto, pensado até meados do século XX. Em primeiro momento, consideramos espaço em seu sentido genérico, abstrato e físico: como forma, extensão relacional entre pontos, linhas e coisas, suportando várias dimensões e contendo corpos e objetos, mas também dimensionando os corpos e objetos.

Além da fisicalidade do espaço, como primeira aproximação, importante destacar que ela também é uma construção social articulada a inúmeros vetores, tais como políticos, sociais, econômicos e culturais (SANTOS, 1996). E as referências de direção definidas pelos pontos cardeais se constituem em premissa importante para diferenciar pontos e lugares e ordenar o espaço, entretanto são elaboradas historicamente à medida que os universos urbano e rural/agrícola se expandem ao longo dos séculos XIX e XX em São Paulo. E nessa perspectiva, a documentação trabalhada aponta para a expressão do espaço como território, e aqui o ponto de partida é Foucault: território está sob abrangência do poder político e jurídico de um Estado, "aquilo que é controlado por certo tipo de poder" e demanda a ideia de nacionalismo; enquanto região remete-se à noção "fiscal, administrativa e militar", mas também está articulada a uma identidade e a algo em nível simbólico (FOUCAULT, 1982). E a reflexão de Guattari (1985) ilumina as fontes, por trabalhar o território na perspectiva cultural, identidades desenham limites e lógicas tecidas por fios de significação elaborados em relações simbólicas.

\section{Do século XIX ao século XX - configuração e reconfiguração do território}

Em meados do século XIX, o oeste de São Paulo era apresentado como próximo da Capital, abrangia a região de Campinas. Um exemplo é o texto de Robert Slenes (1997), Senhores e subalternos no oeste paulista, em que a sociedade analisada é aquela assentada na região de Campinas. ${ }^{2}$ Além desse espaço definido como oeste, havia alguns pequenos vilarejos até o trecho onde hoje pode ser chamado de centro do estado. ${ }^{3}$ Embora toda a área marcada pelos limites administrativos fosse constituinte da sociedade paulista, não era precisamente dessa maneira que parte significativa dos governantes, profissionais e estudiosos considerava o estado de São Paulo do período. Havia uma fronteira imaginária conceituadora dos espaços físicos e hierarquizadora dos elementos sociais, e uma das linguagens que expressava essas diferenças eram as manchas cartográficas, representações imagéticas de projetos políticos de conhecimento e domínio do território (CAVENAGHI, 2004). E o território que assentava a sociedade era, segundo o pensamento predominante do século XIX, aquele em que havia infraestrutura urbana, instituições mantenedoras dos 
valores, regras e tradições dominantes (LOSNAK, 2010); era o espaço marcado pelas cidades formadas por ruas, praças, igrejas e edificações particulares, tendo a presença dos poderes constituídos (executivo, legislativo e judiciário) e de suas edificações, de clubes sociais, da imprensa, representações de partidos políticos, de atividades produtivas inseridas no mercado e articulada a redes de transportes e comunicação. Segundo esse pensamento, além do território social estruturado em inúmeros elementos urbanos, havia o "sertão". A separação e distinção pressupunham que o oeste era a parte extrema ocidental, enquanto o "sertão" estava espacialmente além e socialmente aquém (ARRUDA, 2000).

As cidades que ficavam na fronteira entre o "sertão" e a "civilização" costumavam ser chamadas de "boca de sertão", eram o ponto de conexão e o liame entre dois territórios com valorizações sociais diferenciadas. ${ }^{4}$ As tabelas e mapas apresentados pela publicação Província de São Paulo com informações dos anos 1870 (GODOY, 2007) deixam visualmente claras as manchas da sociedade com base em dados econômicos e demográficos. Nessa lógica, uma área perdia as características naturais quando passava a ser ocupada pela sociedade moderna estruturada, mapeada pelos engenheiros, cortada por vias de comunicação, quando incorporava inúmeros elementos da modernidade e era habitada por uma população considerada "civilizada". ${ }^{5}$

Segundo Amado (1995), o "sertão" como uma categoria esteve presente na caracterização de áreas brasileiras, e do Brasil, desde o início do periodo colonial. Para os portugueses, ele estava ligado ao outro, à alteridade e atravessou séculos com variações de significados, foi aplicado a diferentes lugares e utilizado por diversos autores nacionais nesses cinco séculos. Arruda (2000) defende que o tema está intrinsecamente ligado à formação das identidades, é baseado na memória e na experiência social e, no decorrer do século XX, intensificou-se a oposição entre cidades e "sertões" alimentando a inferiorização desses espaços e de suas populações.

Na continuidade da expansão da sociedade paulista estruturada na direção ocidental, no decorrer da segunda metade do século XIX, o território até então pouco explorado recebeu novas formas de ocupação. O oeste estava em movimento, havia se deslocado para São Simão, Araraquara, Jaú e Botucatu. O livro produzido por Godoy (2007) apresenta dados demográficos obtidos em 1870-71 e elenca os municípios situados no "oeste" daquele momento: Itapeva, Itapetininga, Lençóis, Araraquara, Jaboticabal, São Simão e Franca.

As áreas ocidentais além dessas cidades ainda eram pouco conhecidas. A informação presente nos mapas caracterizadora da região destacava "terrenos desconhecidos" ou "habitados por índios". Sabia-se pouco sobre os rios, a vegetação, o relevo, o solo e os grupos indígenas. ${ }^{7}$ A despeito disso, famílias de agricultores pobres, muitos deles de origem mineira, pontilhavam esse interior. Era uma população rural voltada para atividades de subsistência, com alguma produção de gado e porcos para o mercado, assentada em terras contíguas a espaços de circulação indígena e parte dela sem título de propriedade (ANDRADE, 1945; COBRA, 1943). 
Utilizando as categorias discutidas por Martins (1971), podemos dizer que essa área poderia ser chamada de "frente de expansão": estava além da fronteira econômica, tinha relações com a economia de mercado, mas com produção voltada para a subsistência em primeiro lugar e, em segundo, para a venda do excedente; a apropriação da terra era por posse e não por compra; absorvia o excedente demográfico da sociedade não contemplado na economia de mercado. A partir do início do século XX, esses moradores foram perdendo espaço e terras para novas territorialidades constituídas por grandes fazendas centradas na produção cafeeira, por instalação de linhas ferroviárias e pelo surgimento de cidades. A sociedade paulista ampliava-se no espaço e desdobrava-se reproduzindo suas instituições em novas áreas e novo oeste.

Há consenso de que esse processo teve por movimento dominante a expansão da produção cafeeira que estava integrada à economia internacional do comércio e consumo do café, do sistema bancário e da produção industrial (MATOS, 1990; MONBEIG, 1984, FRANÇA, 1960). Terras novas, muitas delas mais férteis do que aquelas das áreas já exploradas, disponíveis e mais baratas de origem devoluta, e com utilização de novas levas de trabalhadores de baixo custo, entre outras questões, teriam possibilitado e suscitado o alargamento do cultivo do café. As transformações demandavam inúmeros componentes: grande contingente de trabalhadores nacionais e imigrantes; instalação das ferrovias; atividades comerciais e industriais de apoio à agricultura e baseadas nas áreas urbanas; loteamento de terras urbanas e rurais; serviços em torno das redes de transporte e comunicação integrando várias regiões; instituições político-partidárias representativas de interesses da agricultura; complexização das unidades urbanas a partir da concentração desses componentes nas localidades.

O movimento, com ritmos heterogêneos e localizados, atingiu seu limite espacial em alguns pontos das barrancas do rio Paraná, no início do século XX, mas no decorrer de décadas seguintes, as transformações continuaram com a formação de cidades, a implantação de leitos ferroviários, a chegada de trabalhadores nacionais e estrangeiros, o comércio de terras, o assentamento de novas populações no campo, variação da produção agrícola. ${ }^{9}$ Em poucas décadas estava delineado potencialmente o novo oeste, que se tornou a parte mais ocidental da atual conformação territorial do estado de São Paulo, mas em movimento de formação que não era homogêneo e contínuo no espaço e no tempo. ${ }^{10}$ As localidades mais ocidentais tendem a surgir em tempos posteriores às menos ocidentais, mas há dinâmicas diferentes para urbes situadas na mesma linha latitudinal. ${ }^{11}$

Em relação à ferrovia, é importante ponderar que, embora os assentamentos dos leitos ferroviários tenham aberto novas vias de comunicação, demandando derrubada de matas, e cortado campos, essas vias não foram as primeiras a rasgar a região. Há informações indicando a existência anterior de caminhos e planos de abertura de estradas. Nos anos 1860, houve discussão na vila de Botucatu, que demandou reivindicações ao governo do Estado, sobre a necessidade de abertura de estradas para atender aos moradores distantes 
(DI CREDDO, 1993). Os habitantes solicitavam estratégias de combate aos indígenas e a abertura de uma via para o Vale do Paranapanema, no sentido das atuais cidades Espírito Santo do Turvo e Campos Novos Paulista, e outra via no sentido de Lençóis Paulista, Bauru e Salto de Avanhandava. Vale ressaltarmos que as reivindicações pressupunham a existência de caminhos, apesar de precários, para carroças e transporte de cargas, e eram indicadoras da presença de uma população que circulava e já criara espaços organizados. Especula-se também que esses moradores utilizassem trajetos remanescentes dos caminhos indígenas e Holanda (1990) comenta sobre a existência de uma picada aberta em meados do século XVIII ligando Sorocaba ao rio Paraná. Demandaria uma pesquisa o mapeamento das vias existentes ao longo do território que contornaria a São Paulo do final do século XIX, mas esses apontamentos já permitem indicar que as ferrovias não eram instaladas no vazio, pensamento muito difundido na época. Elas eram formas modernas de domínio do espaço, implantando tecnologias produzidas pela revolução industrial, mas não inauguraram a circulação pelo "sertão", apenas a reformularam sob novos modelos, transformando a dinâmica espacial.

Quando, em 1904, Cornélio Schmidt percorreu uma vasta região, indo do extremo norte ao sul, raríssimas vezes precisou abrir picadas (SCHMIDT, 1961). O diário do engenheiro indica que ele percorreu caminhos existentes e, na maior parte das noites, teve pouso em casas de sertanejos. No sentido noroeste, percorreu a Estrada do Taboado que ligava Jaboticabal ao Porto de Taboado, à beira do rio Paraná, próximo da atual cidade de Rubinéia. Ela seria uma conexão entre São Paulo e Cuiabá. Schmidt descreve o caminho como sendo meio abandonado e perigoso pela presença de assaltantes. Próximo a essa região, havia o Caminho de São Bento de Araraquara ligando a cidade de Araraquara a Minas Gerais. Era uma rota para atingir o Mato Grosso e foi utilizada por Alfredo d'Ecragnolle Taunay, em 1867, na volta da Guerra do Paraguai, passando por São José do Rio Preto e São Francisco de Sales-MG (COSTA, 2001).

No lado sul, quando Schmidt passou de Conceição de Monte Alegre e foi até a habitação do morador tido por mais distante, ele cruzou com a trilha oriunda da estrada aberta pelo engenheiro Olavo Hummel, em 1894. A via fora criada por decisão do governo estadual e visava à comunicação com o sul do Mato Grosso, atingindo o rio Paraná num ponto ao sul da foz do rio Santo Anastácio. Tudo indica que o trânsito entre os dois Estados não foi concretizado naquela década. Permaneceu a via tradicional de transporte de gado que ia até Paranaíba, passava por Minas Gerais e depois entrava em São Paulo. Posteriormente, um novo projeto surgiu. Mediante contrato com o governo, a firma Diederichsen \& Tibiriçá abriu outra estrada ligando Campos Novos Paulista até o porto Tibiriçá percorrendo parte do mesmo trajeto criado por Olavo Hummel. Do outro lado do rio Paraná, o criador de gado conhecido por Major Cecílio abrira uma via ligando o Porto 15 de Novembro a Campo Grande, também objetivando explorar o transporte e transbordo de gado. Abreu (1976) argumenta que essas empreitadas já tinham perspectivas empresariais. Com o trecho paulista pronto e a compra da concessão de Major Cecílio, criou-se, em 1908, a empresa 
Companhia Viação São Paulo-Mato Grosso que foi mantida durante anos como estrutura de transporte de gado entre o sul de Mato Grosso do Sul e São Paulo e conectando-se às pontas de linha da Estrada de Ferro Sorocabana.

As informações sobre a existência de caminhos e a abertura de estradas indicam o lento processo de apropriação da área que se modificou conforme as vias se tornavam mais eficientes rotas de mercadorias. A marca temporal da intensificação da chegada dos moradores no extremo oeste é o último quartel do século XIX, em movimento autônomo à política estatal e às dinâmicas de mercado. Os moradores dessas áreas foram chegando, apossando-se de terras, ocupando ou comprando, registrando e alguns depois dividindo (COBRA, 1943; ANDRADE, 1945). Os caminhos foram abertos à medida que os assentamentos rumavam mata ou campo adentro e estabeleciam conexões entre propriedades e pequenos agrupamentos. Com a mercantilização da terra e a produção para a exportação, em fins do século XIX, a ocupação começou a adquirir dinâmica com predominância da economia de mercado.

Nesse sentido, as ferrovias podem ser consideradas um caso exemplar de modernidade no início do século XX, acelerado pelo poder republicano e por onde se cruzavam diversas questões (HARDMAN, 1991; CASTRO, 1993). Houve, no período, um projeto de unificação e integração nacional do território e do poder político no governo federal, passando pela construção de ferrovias, pela instalação de uma rede de telégrafo, pelo reconhecimento e mapeamento de áreas desconhecidas nomeadas de "vazias", pela incorporação das populações imigrantes, pelo debate em torno do nacional (ARRUDA, 2000; SEVCENKO, 1983; NAXARA, 1998).

Por outro lado, para matizar a presença do fator ferroviário na formação do território é importante explicitar que as ferrovias não foram instaladas de maneira homogênea e cada uma possuía sua especificidade. Elas eram produtos da articulação entre projetos nacionais, do governo do Estado e de interesses dos cafeicultores. No caso das linhas paulistas e, especificamente, nas redes instaladas no decorrer do século XX no novo oeste, diversas velocidades moviam as expansões, inclusive de uma mesma companhia. As diferenças eram decorrentes das questões internas, tais como a viabilidade econômica e a estabilidade financeira da empresa, e articuladas às questões como a produção econômica das áreas de ocupação, o comércio de terras, os poderes políticos organizados com interesses em jogo, a conjuntura econômica nacional e internacional (o preço do café) e interesses empresariais. Observando as datas de instalação das linhas notamos que as cronologias são díspares, por exemplo:12 a Companhia Paulista de Estradas de Ferro de capital privado, criada em 1868, que teve o trecho entre Jundiaí e Campinas inaugurado em 1872, chegou a Agudos em 1903, atingiu Panorama, na divisa com o estado do Mato Grosso do Sul apenas em 1962;13 a Estrada de Ferro Sorocabana foi fundada em 1871, atingiu Botucatu em 1889 e chegou a Porto Epitácio, à beira do rio Paraná, em 1922; a Estrada de Ferro Araraquara, também de capital privado, partiu de Araraquara em 1896 e chegou a Rubinéia, à beira 
do rio Paraná em 1952. ${ }^{15}$ A velocidade mais rápida de implantação foi a Estrada de Ferro Noroeste do Brasil que partiu de Bauru em 1905, chegou ao rio Paraná em 1910 e teve concluído o trecho até Porto Esperança, à beira do rio Paraguai, em $1914 .{ }^{16} \mathrm{Com}$ exceção desta última, as datas de implantação de continuidade de assentamento indicam vários periodos de interrupção.

Apesar das diferenças, a ferrovia apresentava-se como elemento configurador das dinâmicas territoriais do novo oeste, a partir da primeira década do século XX, e com forte poder de interferência (SANTOS, 1992). Ela era resultante dos interesses estatais e privados, organizava o espaço em áreas de domínio e exclusividade de cada empresa, integrava essas novas áreas à economia global com lógicas diferentes daquelas dos antigos moradores, sertanejos e indígenas. Estado, empresas e profissionais planejaram e administraram o corte do espaço reorganizando-o, criando reconfigurações simbólicas em torno dele, inserindo inovadoras tecnologias de comunicação e de transporte seguindo a lógica do capital investido, a perspectiva de aberturas de mercados, novas fontes de mercadorias e ampliação das possibilidades de comércio. Os territórios dos antigos moradores ${ }^{17}$ foram esfacelados pelo confronto de duas sociedades contrastantes e poderes diferenciados. Esse processo foi considerado natural e interpretado como decorrência do crescimento da economia paulista do início do século XX que estava envolto à crença no progresso, anunciadora de novos tempos e associada à memória do bandeirantismo paulista (QUEIROZ, 1991).

\section{Ferrovia e cidades}

É consolidada a interpretação de que houve fortes vínculos entre a expansão ferroviária e a formação de parte das cidades no extremo oeste do Estado, redefinindo o território e abrindo nova lógica de ocupação (MONBEIG, 1984; FRANÇA, 1960; MATOS, 1990; GHIRARDELLO, 2002). Com a intenção de identificar essas relações e matizar alguns pontos, diante da impossibilidade de reconstruir o processo de instalação de cada linha ferroviária, apresentamos algumas reflexões sobre a área de influência da Estrada de Ferro Noroeste do Brasil (NOB) e sobre relações entre essa ferrovia e a formação das urbes ao longo da via no trecho paulista. Trilhos, malhas urbanas e fazendas redesenharam o espaço, dinamizaram as lógicas de ocupação com atores diferenciados e balizaram representações sociais atribuidoras de significados viabilizadores de novos territórios.

A Noroeste do Brasil já era objeto de projetos desde 1890. Havia a previsão de um trajeto entre Uberaba-MG e Coxim-MT. Em 1904, pouco antes do início da construção, decidiu-se pelo ponto de partida em Bauru, rumando diretamente para o rio Paraná e, a partir dali, para Cuiabá. Durante a construção houve alteração do traçado com ponto final em Corumbá. Queiroz $(1992,2004)$ aponta os interesses geopolíticos em criar uma via direta entre a capital do país e o Mato Grosso, nos limites com o Paraguai e a Bolívia, prescindindo da via fluvial pelo rio Paraguai, que era utilizada até então, e aproximando o atual estado do Mato Grosso do Sul aos centros econômicos e políticos. ${ }^{18}$ A ligação econômica entre São 
Paulo e Mato Grosso, bem como com a Bolívia e, posteriormente, Paraguai foram elementos nos horizontes dos planejadores (QUEIROZ, 2004). Outro viés refere-se à construção das ferrovias como um empreendimento em si e esse objetivo também teria ocorrido neste caso específico (QUEIROZ, 1992; MORATELLI, 2009). Vários grupos tinham interesse nas obras, elas eram financiadas por capitais ingleses e franceses, demandavam empréstimos bancários, equipamentos vindos da Inglaterra, profissionais e investimentos oriundos da França, contratavam empresas construtoras empreiteiras, abriam oportunidade de emprego para múltiplos espectros de trabalhadores e demandavam a engenheiros empenhados em obras, negócios e reconhecimento social. Depois de concluídas, continuavam a ser empresas voltadas para o serviço do transporte.

A empreitada era de iniciativa do governo federal com vultosos investimentos e com garantia de lucros das empresas construtoras. Em cerca de nove anos a obra percorreu aproximadamente $1270 \mathrm{~km}$, cortando os dois Estados. A particularidade da implantação dessa linha é que ela desbravou uma área ainda coberta de mata, ocupada por índios, cortada por rios recentemente explorados pelas expedições da Comissão Geográfica e Geológica de São Paulo e sem unidades urbanas. ${ }^{19}$ Embora no trecho inicial, entre Bauru e Pirajuí, já houvesse fazendas cafeicultoras, toda a área era reduto de vida dos Caingangues (ANDRADE, 1945; LIMA, 1978; PINHEIRO, 1992, 1999) e sofreria rápidas transformações, alterando radicalmente os assentamentos e as lógicas de ocupação. Segundo a interpretação do binômio café-ferrovia, a perspectiva era de que a linha facilitasse o acesso aos grandes produtores da região (MONBEIG, 1984; FRANÇA, 1960; MATOS, 1990). Em uma década, o território deixaria de ser domínio dos índios para expressar poder das companhias ferroviárias, dos grandes proprietários e de nova população que almejava abocanhar parte do que seria considerado um novo eldorado (FERRAZ, 1924).

No trecho paulista da Noroeste, particularmente entre Bauru e Araçatuba, as cidades foram surgindo estimuladas pelas movimentações do fluxo ferroviário e, posteriormente, otimizando a produção cafeeira. A chegada dos trens, a inauguração da estação, ou ainda uma base de apoio para o tráfego, tal como a chave de linha, garantiam o início do negócio promissor de terras, e os investimentos nas áreas rurais, o despontar de unidades urbanas em virtude de demandas de serviços, negócios e movimentos populacionais, entretanto cada uma revelou sua dinâmica específica de crescimento, formando hierarquias entre elas e respectivos desdobramentos na institucionalização administrativa de cada uma.

É possível identificar a linha temporal da transformação do território por meio das datas de consolidação administrativas das unidades urbanas, indicando alteração da ocupação rural/sertaneja/indígena para novas estruturas espaciais, econômicas e sociais em significativa velocidade de mudança. Até a primeira década do século XX, Bauru tinha sua área de município atingindo as barrancas do rio Paraná (BASTOS, 2000). Com a instalação dos trilhos da Estrada de Ferro Noroeste do Brasil, a formação dos vilarejos e a intensificação dos empreendimentos de terras, agrícolas e comerciais configuraram a ocupação que 
gradativamente ia se ordenando e modificando a hierarquização administrativa das urbes. No trecho entre Bauru e Araçatuba, inaugurado até 1908, as cidades desenvolveram-se inicialmente baseadas na agricultura cafeeira, articulada à venda de terras e, décadas depois, foram diversificando a produção. Aquelas que mantiveram atividades econômicas mais intensas destacaram-se com o crescimento e sediaram poder político mais articulados, tais como Pirajuí, Lins, Penápolis e Araçatuba (FERRAZ, 1924; ERCILLA; PINHEIRO, 1928; BEOZZO, 1969; MARTINS, 1968). ${ }^{20}$

Na ordem de posicionamento da linha, de Leste para Oeste, estão os municípios e as suas principais datas de mudanças administrativas: 1- Avaí - criado o distrito em 1910 e o município instalado em 1920; 2- Presidente Alves - criado o distrito em 1914 e o município instalado em 1928; 3- Pirajuí - criado o distrito em 1907, o município instalado em 1915 e a comarca iniciada em 1920; 4- Cafelândia - criado o distrito em 1919, o município instalado em 1926 e a comarca iniciada em 1934; 5- Lins - criado o distrito em 1913, o município instalado em 1920 e comarca iniciada em 1928; 6- Avanhandava - criado o distrito de Miguel Calmon em 1909 e instalado o município de Avanhandava em 1927; 7- Promissão - criado o distrito de Hector Legru em 1919, instalado o município de Promissão em 1924 e iniciada a comarca em 1944; 8- Penápolis - criado o distrito em 1909, o município instalado em 1913 e iniciada a comarca em 1917; 9- Birigui - criado o distrito em 1914, o município foi instalado em 1922 e a comarca iniciada em 1934; 10 - Araçatuba - criado o distrito em 1917, o município instalado em 1922 e a comarca iniciada no mesmo ano (INSTITUTO BRASILEIRO DE GEOGRAFIA E ESTATÍSTICA, 1957).

As datas elencadas, de criação do distrito e depois de elevação a município, não obedecem rigidamente à linearidade espacial e nem ao tempo imediato da instalação dos triIhos da Noroeste. Sem entrar em detalhes de cada caso, embora a instalação da ferrovia fosse um condicionador, pois todos os distritos surgiram após a chegada da linha, outros fatores interferiram no processo, tais como o empenho político de grandes fazendeiros em criar a vila e seu reduto eleitoral (Penápolis) e em lançar grandes empreendimentos de terras (Promissão, Birigui, Araçatuba) (MARTINS, 1968; CONSTANTINO, 2010). Pode ser indicada também a pujança econômica de fazendas cafeeiras (Pirajuí, Cafelândia e Lins) que em alguns casos se desdobra em inúmeras dinâmicas, por exemplo, a maior incidência de assentamento de imigrantes japoneses que se tornaram colonos e pequenos proprietários rurais e áreas de intensa produção cafeeira nos anos 1920 (BEOZZO, 1969). A exceção parcial é Pirajuí, pois a linha-tronco passava pelas principais fazendas já existentes e não pela cidade. ${ }^{21}$ Apesar da distância, a vila cresceu, tornou-se economicamente importante, obteve a sede da comarca sem ainda estar à beira da linha. Apenas em 1925 foi construído o ramal garantindo a conexão com a área urbana e, anos depois, a retificação da linha-tronco possibilitou-a cruzar a cidade (NEVES, 1958).

Segundo Ghirardello (2002), as urbes criadas no primeiro trecho construído, entre Bauru e Araçatuba, tiveram o desenho urbano em diálogo com a estação e com a linha. A 
partir de ambas, era feito o desenho com predominância do traçado em xadrez, marcando o espaço em quadrícula, organizando as vias sem muita preocupação com adaptação delas à elevação do terreno, sugerindo a percepção espacial e o movimento dos moradores por meio de linhas previsíveis e reproduzidas até os limites da urbe. Os cruzamentos de linhas retas estavam presentes em todas as cidades e as unificava pela repetição, marcando claramente a continuidade perceptiva do novo território, ao mesmo tempo em que se aproximava das enfileiradas linhas de cafeeiros percorrendo o horizonte das fazendas, e ambas se contrapunham à imagem irregular da vegetação do campo e da mata (FERRAZ, 1924).

Enokibara (2010) identifica a aproximação temporal entre a chegada dos trilhos, a formação da urbe e a transformação dos largos, normalmente em frente à matriz, em praças construídas segundo desenhos consagrados, com arborização, equipamentos e materiais, como o coreto de ferro, semelhantes a alguns da capital paulista. Materiais, espécies vegetais e profissionais circulavam pelas linhas e possibilitavam o desenho de novas paisagens, que se contrapunham à do campo e à da mata, criavam cenários considerados urbanos "civilizados", aprazíveis ao lazer e à sociabilidade, e contribuíam para marcar as mudanças do território e de respectivos hábitos de urbanidade que permitiam a tessitura da autoimagem de seus moradores pretensamente equiparada a dos habitantes da capital do Estado.

A determinação da presença da ferrovia é também válida para as cidades do trecho entre Araçatuba e o rio Paraná em décadas posteriores. Elas surgiram nos anos 1930, a partir da construção de uma nova linha no alto do espigão, longe do insalubre vale do rio Tietê (PELEGRINA, 2000; QUEIROZ, 2004). ${ }^{22}$ Nessa rota, trecho iniciado em 1926 e concluído em 1937, mas com decreto federal aprovando a obra em fins de 1922 (QUEIROZ, 2004), embora já existissem propriedades em áreas próximas a Araçatuba e até algumas aglomerações (Guararapes, em 1908, por exemplo), a perspectiva de assentamento dos trilhos foi decisiva para o negócio de terras e a formação das urbes. ${ }^{23}$ Como em outras ferrovias, a previsão da construção do trecho indicava a possibilidade de investimentos na área. Conforme as datas elencadas em nota indicam, as cidades foram se formando linearmente e de maneira gradativa à medida que os trilhos iam sendo assentados, as estações inauguradas e conectadas à linha que se tornaria principal.

Nesse movimento, alguns proprietários teriam se antecipado à chegada do trem e lotearam glebas previstas para serem cortadas pelos trilhos e sediarem estação para passageiros, tais como Lavínia e Mirandópolis (INSTITUTO BRASILEIRO DE GEOGRAFIA E ESTATÍSTICA, 1957). E há casos com razoável antecedência, como por exemplo, quando, em 1917, parte da fazenda Barra do Tietê foi comprada pela empresa Colletes, Moura Andrade \& Cia, se tornaria grande criadora de gado e mais tarde fundadora da cidade de Andradina (CONSTANTINO, 2010). Constantino (2010) e Ghirardello (2002) identificam que parte significativa das cidades criadas nas primeiras décadas do século XX no novo oeste não se originou de patrimônios religiosos e sim, como Presidente Alves, Cafelândia, Promissão, 
Glicério, Birigui, Araçatuba e Andradina, por meio de parcelamento de fazendas e vendidas pelos proprietários. Era uma estratégia dos donos para criarem a urbe e atuarem no ramo de negócios de terras.

Ao mesmo tempo, perspectivas territoriais mais amplas eram valorizadas por moradores do novo oeste. Uma característica da Estrada de Ferro Noroeste do Brasil é que ela seguia para o atual Mato Grosso do Sul e atingia o rio Paraguai, Porto Esperança, próximo da Bolívia. A estrutura visava ao transporte e à comunicação de São Paulo com essas áreas fronteiriças e garantia um fluxo que permitia a inserção das cidades numa extensa rede viária, aproximando territórios diferenciados. É nessa perspectiva que o Diário da Noroeste publica uma pequena nota anunciando a existência de um projeto de ferrovia "transcontinental" interligando o Brasil e a Bolívia. O diário menciona a passagem por Bauru do engenheiro Estanislau Luiz Bousquet, "lente da escola politécnica do Rio de Janeiro e comissionado pelo governo para estudar o projeto de uma linha" entre Porto Esperança e Santa Cruz de La Sierra. ${ }^{24}$ Bousquet não estava só, era acompanhado por uma equipe de dez engenheiros. O redator menciona que o empreendimento era resultante da obrigação do Brasil, definida pelo tratado de Petrópolis, assinado em 1903, de construir uma ferrovia para ligar a Bolívia ao litoral. ${ }^{25}$ E é a partir dessa perspectiva que Queiroz (2004), ao analisar a Noroeste, a intitula "uma ferrovia entre dois mundos", pois mesmo antes de ser construída era pensada como conexão com os países fronteiriços. ${ }^{26}$

No mês seguinte, janeiro de 1926, o periódico destaca em primeira página a reprodução de matéria publicada no jornal Diário da Noite dando detalhes do projeto e enfatizando a importância dele para o Brasil, para os países vizinhos e a latinidade sul-americana, em virtude da integração econômica e política. ${ }^{27} \mathrm{O}$ texto é adjetivado e laudatório à obra, típico do jornalismo da época, mas nos informa como a ferrovia estava sendo pensada por aqueles que possuíam algum vínculo com a região. A intenção era fazer a conexão Santos-Arica, ligando o Atlântico ao Pacífico, numa extensão de 4.000 km, mas que faltava construir o trecho de 1.200 km entre Cochabamba e Porto Esperança. ${ }^{28} \mathrm{Na}$ Bolívia, essa linha seria ligada às redes vindas do Chile e do Peru, somadas a intenção de também estender outra via para a Argentina. ${ }^{29}$

A justificativa apresentada para a obra foi a necessidade integrar os países, romper a política isolacionista da região e levar a "civilização", que chegava pelos litorais, aos "sertões" ignorados. O redator afirma que quem teria vislumbrado essa proposta fora o Barão do Rio Branco expresso no tratado de Petrópolis, mas enfatiza que nos 1920 os engenheiros estariam superando os políticos por concretizarem o grande projeto idealizado décadas antes. ${ }^{30} \mathrm{Na}$ perspectiva do jornalista, o saber técnico propiciava a implantação do "progresso" nos interiores, e os profissionais eram considerados os agentes da transformação do território. A obra seria bem-vinda para Bauru e o redator avaliava que a cidade passaria a estar inserida em rede mais longa e complexa. Além do interesse do tema pela importância política e econômica nacional de integração dos países pelos trilhos, o redator 
sugere reconhecer a relevância da posição estratégica de Bauru nessa rede internacional por ser o ponto de partida da via que aproximaria São Paulo e o país a "outros mundos" e, portanto a cidade seria o nó de conexão entre diferentes territórios. E o jornal dessa cidade seria alçado em mesma proporção, facilitando a eventual circulação para áreas mais distantes e quiçá a conquista de maior contingente de leitores. E, nessa perspectiva, a ferrovia era considerada um meio estratégico de expansão da empresa jornalística.

\section{A territorialidade marcada pela rede ferroviária}

A presença da ferrovia nas páginas dos jornais de Bauru não era novidade naquele ano de 1926. Desde a primeira década do século XX, elementos do sistema ferroviário perpassavam o debate político, a organização simbólica do território e foram registrados pela imprensa regional. Jornais e livros noticiavam e informavam sobre processos e acontecimentos, recortavam-nos por meio da centralidade da ferrovia na constituição do espaço, das dinâmicas econômicas e das interpretações dos processos. Tendências dominantes na formação e transformação do território eram entendidas como desdobramentos do funcionamento das linhas férreas.

O Baurú, veiculado desde fim de 1906, era um pequeno jornal criado por líderes de um grupo do PRP local e publicava, durante o período de construção da Estada de Ferro Noroeste do Brasil, artigos e manchetes com informações sobre as obras e seus desdobramentos, bem como as perspectivas futuras da empresa. Os engenheiros eram apresentados como técnicos que informavam sobre a área desconhecida que seria ocupada, que detinham conhecimentos para transformar o espaço "natural" considerado inadequado aos futuros moradores, como empreendedores que financiavam e conduziam as obras e eram portadores de políticas transformadoras da região. ${ }^{31}$ Por a cidade sediar as estruturas administrativas da construção no trecho paulista da Noroeste, entre 1905 e 1910, e posteriormente também da Companhia, era estreito o vínculo da sociedade local com a ferrovia, suas instituições e seus valores. Importante destacar que a ferrovia era financiada por verba federal, a Presidência da República marcava forte presença e articulava relações entre os poderes municipal, estadual e federal. A chegada da Noroeste a Bauru, com sede administrativa e base da construção da linha, transformou o vilarejo, adquirindo maior peso político no cenário regional. As visitas de autoridades e periódicas inaugurações de trechos eram cobertas por longos textos laudatórios aos eventos, às autoridades e aos visitantes ilustres, incluindo os engenheiros posicionados em altos cargos.

Ao longo da consolidação da Noroeste, Bauru passou a ser vista como ponto estratégico, pois serviria de conexão entre Santos, S. Paulo, Mato Grosso e outras regiões do Estado por sediar o entroncamento das ferrovias Noroeste, Sorocabana e Paulista. Um exemplo revelador é o artigo, publicado no jornal O Bauru, laudatório à inserção estratégica de Bauru na ampla rede de comunicação e considerando-a decisiva para a mudança de status da cidade. 
A popularidade grandiosa que goza este recanto do Estado de S. Paulo o torna invejado por muitas cidades, entre as quais algumas que se julgam de uma importância extraordinária. É que Baurú, situado em um excelente ponto estratégico, é a única cidade que pode servir de interposto entre S. Paulo e Matto Grosso, e para facilitar-lhe essa tarefa é ponto terminal de duas importantes estradas de ferro, Sorocabana e Paulista, e ponto inicial da não menos importante Noroeste do Brasil (O BAURU, 1922, p. 1). ${ }^{32}$

Naquele período, a ferrovia era entendida como um meio de comunicação de suporte da circulação de materiais impressos e da informação por longas distâncias. Por isso, ao noticiar o projeto da linha Santos-Arica o redator do Diário da Noroeste saudava a possibilidade de ampliar a rede em que estavam inseridos e colocava-se como participante de um ponto na rede transnacional. Por ali passariam trens, cargas, mercadorias, pessoas e informações. A comunicação seria com a capital do Estado e com outros países. A diminuição das distâncias entre diversos centros (Santos, São Paulo, La Paz) era vislumbrada como possibilidade iminente e Bauru se tornaria um ponto na via mais longa de expansão da modernidade, no fluxo da transformação "civilizadora".

Desde o século XIX, a ferrovia era reconhecida com grande força transformadora e criadora, era largamente entendida como expressão do progresso e da modernidade (HARDMAN, 1991; CASTRO, 1993; MANFREDI NETO, 1995). Durante o período de construção, a Noroeste era apresentada nas páginas do jornal O Baurú com essas características, como o veículo da "civilização", transformando o "sertão", emancipando as regiões de fronteira, instaurando o novo tempo e entreabrindo próspero futuro para São Paulo e para as regiões mais distantes. ${ }^{33}$

Atores sociais da região e de outros lugares compartilhavam da perspectiva eufórica e ufanista nas décadas seguintes. Um exemplo é a série de reportagens que o editor de $O$ Estado de S. Paulo, Brenno Ferraz, produziu e publicou no periódico em 1923 e que, em 1924, foi reunida no livro Cidades Vivas (FERRAZ, 1924) pelo editor Monteiro Lobato. Ferraz percorreu a linha da Noroeste entre Bauru e Araçatuba, observou e descreveu as cidades e as sociedades locais, apontou problemas da estrutura da ferrovia e redigiu textos elogiosos ao vertiginoso crescimento da região que se formava, ao empreendedorismo dos colonos, proprietários, anônimos e de autoridades que se amalgamavam no vórtice de "progresso", que negava o passado da natureza infrutífera e barbárica e dava vida às cidades e fazendas produtivas (LOSNAK, 2008). Segundo Ferraz, (1924), as recentes e velozes transformações do território, com a derrubada da mata, a abertura de fazendas, o plantio de café, a expansão das urbes e a próspera economia eram alinhavadas pelos trilhos, eixo condutor de um novo tempo para São Paulo. Os textos dos anos 1920 revelam estar consolidada, naquele momento, a interpretação de que as ferrovias eram elemento definidor na constituição da expansão da sociedade paulista na área do novo oeste.

Na leitura positivista do progresso, os índios Caingangues, que defenderam seu território e resistiram à ocupação e à construção da ferrovia, foram considerados obstáculos. 
Durante as obras da via da Noroeste, inúmeros ataques indígenas ocorreram a grupos de operários no momento do trabalho, em períodos de descanso, à noite e, posteriormente, foram perpetradas invasões de instalações ferroviárias. Os ataques amedrontavam os trabalhadores, inquietavam autoridades e eram reverberados pela imprensa. No jornal $O$ Baurú, os índios eram qualificados de brutais, portadores de "furor canibalesco" em "ataques violentos" ou de modo "bárbaro" ao mesmo tempo que se atribuía a eles o caráter de "inimigos inconciliáveis" por estarem em lado oposto no conflito pela posse da região. ${ }^{34}$ Em outra perspectiva desse mesmo pensamento, afirmou-se que a ferrovia era implantada pela sagacidade de engenheiros, como Saint Martin, que abriam os "sertões" inóspitos, apesar dos "temíveis coroados, indomáveis selvagens". ${ }^{35} \mathrm{~A}$ interpretação dominante era de que os Caingangues representavam ameaça à formação do novo território que, por sua vez, pressupunha a exclusão dos nativos. E as tensões permeavam até mesmo atores politicamente afinados aos trabalhadores.

Em um jornal de linha perrepista - O Baurú - os textos produzidos por um pequeno grupo de redatores de viés anarquista, em permanência efêmera no periódico, explicitaram solidariedade aos trabalhadores da construção da ferrovia, considerados "homens sem pátria, sem família, sem amigos" e sem proteção militar durante as jornadas, "enquanto os índios folgam e se gloriam tendo como símbolos das suas vitórias e alegrias os pedaços mutilados do infeliz trabalhador". ${ }^{36}$ Em determinado momento, o redator de codinome Nero transita entre o protesto pela violência dos indígenas e a consciência de que "mandar exterminá-los é uma injustiça desumana". ${ }^{37} \mathrm{O}$ autor referia-se à prática sistemática dos bugreiros de invadir aldeias e trucidar os moradores nativos, desde o final do século anterior, bem como a ação violenta do exército das empresas construtoras da Noroeste (ANDRADE, 1945; LIMA, 1978). Alguns textos jornalísticos sugeriam a necessidade de responder pelas armas aos ataques desfechados à ferrovia, mas Nero pondera que "deixa-los continuar é um crime que a humanidade não perdoa, porque não se procura garantir a vida de tantos honrados trabalhadores, portanto cumpre ao governo procurar outro meio que dificilmente se acha".

Por fim, na virada da primeira para a segunda década, os índios estavam se aproximando da extinção. Nesse momento, o governo federal assumiu a responsabilidade do problema e o obstáculo indígena foi definitivamente afastado (LIMA, 1978; PINHEIRO, 1992, 1999). ${ }^{38}$ Em 1910, o governo federal criou o Serviço de Proteção ao Índio, em 1911 iniciaram-se providências para controlar os nativos, Candido Rondon visitou a região e, nos anos seguintes, os sobreviventes foram agrupados em dois aldeamentos. Durante décadas os Caingangues foram apagados da memória, a destruição física deles permaneceu silenciada e a ferrovia sobressaiu-se como símbolo fundante da vitória sobre a natureza. ${ }^{39}$ Pelo realce desse conflito, é entreaberta uma perspectiva para relativizar a abordagem que naturaliza a dominância da territorialidade delineada pelo trinômio café-ferrovia-cidade. A resistência Caingangue pode ser entendida como clara afirmação da territorialidade existente na região e constituinte daquela sociedade que perdia espaço diante da nova ocupação que 
avançava sob outra lógica.

Em viés diferenciado, os trabalhadores da construção da linha e de outros matizes esboçavam organização política na nascente Bauru e emitiam seus discursos por meio de representantes atuantes no impresso O Baurú, principalmente no período entre 1908 e 1910, que era dirigido pelo ex-ferroviário e militante anticlerical Almerindo Cardarelli. Os redatores denunciavam as dificeis e insalubres condições de trabalho nas obras, problemas de pagamento dos salários, tratamentos arbitrários e deficiências de alimentação, mas também o jornal divulgava a existência de reuniões e manifestações de entidades operárias. As empresas construtoras eram responsabilizadas pela exploração e o desamparo social em que viviam, a despeito de terem migrado de várias regiões e até de outros países para viabilizarem a construção da linha (NEIVA, 1927; CASTRO, 1993; MORATELLI, 2009). A organização operária foi fortalecida nas décadas seguintes (MOMESSO, 1988; GRANDI, 2008; CARVALHO, 2008) e sinalizava para a existência do espaço da identidade dos assalariados que se opunham à onipotência da empresa ferroviária e, por esta razão, marcavam elementos da subjetividade que, segundo Guattari (1985), se constitui no território de expressão cultural e política.

No movimento de interpretação marcada pela inevitabilidade do predomínio da ferrovia, e em meio à variedade de configurações simbólicas do território na memória dominante do período, uma questão que se destaca no estado de São Paulo é a denominação "Zona". Nos projetos e contratos de construção das ferrovias estava prevista uma área exclusiva de atuação de cada companhia, garantindo certa equidistância entre elas e desenhando a territorialidade administrativa (SAES, 1981) e, no novo oeste, desenhava certa linearidade no eixo leste-oeste e paralelismos entre as linhas no sentido norte-sul. E assim foram surgindo as denominações "Zona Mogiana" (correspondente ao âmbito da Companhia Mogiana de Estradas de Ferro), "Zona Sorocabana" (além de "Baixa Sorocabana" e "Alta Sorocabana"), "Zona Paulista" (incluindo "Baixa Paulista" e "Alta Paulista") e "Zona Araraquarense" (incluindo a "Alta Araraquarense") (LOVE, 1982). Santos (1992) analisou esse processo e identificou a força da representação da ferrovia, a ponto de recortar o espaço de São Paulo, atribuindo inteligibilidade ao território segundo a dinâmica ferroviária. $O$ autor observa que essa categorização perpassava classes sociais, regiões, produção intelectual e científica. Cabe destacarmos que Love (1982) e França (1960) reproduziram essa territorialidade marcada pela administração ferroviária.

Um exemplo da força simbólica e agregadora dessa representação é o livro São Paulo - Zona Noroeste (ERCILLA; PINHEIRO, 1928). Ele foi lançado em 1928, em edição bem acabada, com capa dura revestida por tecido, papel diferenciado, tamanho além do usual $(29 \mathrm{~cm} \times 37 \mathrm{~cm}$ ), redigido por jornalistas paulistanos, com texto em quatro línguas (português, espanhol, inglês e italiano), produzido por uma empresa privada e provavelmente financiado pelos proprietários da região. De perfil propagandístico e com características de obra oficial, o objetivo era divulgar a região entre empresários interessados em investir 
em fazendas e agronegócios, entre trabalhadores estrangeiros e nacionais em busca de emprego e entre possíveis compradores de lotes no campo. A obra apresenta as principais autoridades do governo do Estado e do Partido Republicano Paulista, historia a ocupação da "Zona Noroeste" a partir da construção da ferrovia e elenca todas as cidades que estavam à beira da linha, entre Bauru e Araçatuba, inserindo fotos, dados econômicos e populacionais, registrando as principais empresas e fazendas, definindo algumas características de cada localidade. O intuito era realçar a pujança da região e demonstrar que ela prometia prosperidade a todos que chegassem dispostos a trabalhar e investir. A obra mescla propaganda da região, autoimagem das elites locais e vitrine das forças políticas perrepistas. Indica, também, que a representação social "Zona Noroeste" tornava-se, naqueles anos 1920, independente do nome da companhia ferroviária, a ponto de descolar-se e permanecer na memória social. ${ }^{40}$

A mesma perspectiva presente nos dois livros em torno da territorialidade delineada pela ferrovia Noroeste (FERRAZ, 1924; ERCILLA; PINHEIRO, 1928) era veiculada pela imprensa periódica dos anos 1920 e nas décadas seguintes. Em Bauru, entre 1925 e 1930, foi publicado o jornal Diário da Noroeste com perfil editorial de circulação pelas cidades que estavam à beira da linha da Estrada de Ferro Noroeste do Brasil. De um grupo de profissionais liderados por dois funcionários da Companhia, João Maringoni e Correia das Neves, o periódico teve o título composto por elemento de tempo, a periodicidade de circulação (diário), e elemento de espaço, referente ao território atribuído à empresa (Noroeste).

No período inicial de publicação, evidenciava-se estreito vínculo com ela, havia notas oficiais da Companhia e matérias locais, nacionais e internacionais, mas o diferencial era enunciar-se como representante da "Zona Noroeste", publicar textos de interesse da região, conter anúncios de empresas e serviços das cidades postadas ao longo da linha e anunciar a circulação, por essas urbes, do representante comercial vendedor de assinaturas. Uma das estratégias jornalísticas foi a criação da seção "Notícias da Zona" que concentrava notas sobre acontecimentos dessas cidades e abrangia localidades do atual estado do Mato Grosso do Sul (Avaí, Presidente Alves, Pirajuí, Lins, Cafelândia, Penápolis, Promissão, Araçatuba, Três Lagoas, Campo Grande e Aquidauana). Eram reportados diversos tipos de ocorrências e assuntos, tais como, festas, falecimentos, inaugurações, problemas urbanos (doenças e questões sanitárias, iluminação pública, abastecimento de água, rede de esgoto, melhoramentos), economia regional, problemas de eficiência da ferrovia, criminalidade. No ano de 1926, o jornal apoiou movimento de prefeitos da região para se reunirem e debaterem problemas e reivindicações a serem enviadas ao governo do estado. ${ }^{41}$ Nessas matérias, Bauru é apresentada como a "Capital da Noroeste".

O Diário da Noroeste não apoiou o golpe liderado por Getúlio Vargas, em 1930, foi empastelado e não retomou suas atividades. Em 1931, o mesmo grupo de jornalistas criou outro diário, Correio da Noroeste, com perfil editorial semelhante e que também buscava ter circulação regional, inicialmente pelas linhas da Noroeste. Em suas páginas era cons- 
tante a presença de propaganda da disponibilidade de venda de assinaturas e anúncios por meio de representantes nas diversas cidades. O elenco dessas localidades gradativamente se expandia no decorrer da década de 1930 e percorria outras redes ferroviárias. Os jornalistas utilizavam o referencial territorial dominante, ao mesmo tempo que lançavam mão da rede de fluxo estruturada e mais eficiente naquele tempo para garantir a circulação cotidiana do impresso, poder atingir os leitores no mesmo dia e viabilizar o negócio.

Na busca por ampliar a circulação, o Correio se expandia, atingia outros territórios e mesclava vários deles. A alternativa para marcar e anunciar essa representação era o slogan. Em 1934, o Correio estampava impresso, logo abaixo de seu nome, Diário Matutino Das zonas Noroeste, Alta Paulista e Sul de Matto Grosso e, em 1936, Diário Matutino - Das Zonas Noroeste, Alta Paulista, Central e Alta Sorocabana, sul de Matto Grosso e Norte do Paraná. Como estratégia editorial de organizar e apresentar a cobertura das ocorrências desses territórios constavam, nas páginas internas, quadros de diversos tamanhos para noticiar sobre as principais cidades existentes em cada eixo ferroviário, lançando mão do primeiro título do veículo, o nome da empresa ferroviária e, em alguns casos, o setor da linha, tais como Correio da Alta Paulista, Correio da Sorocabana. Esse recurso constituía-se na inserção de pequenas editorias, com o título específico desdobrado do título principal (Correio) e correspondente aos acontecimentos, informações e publicidade daquela região. Por outro lado, o registro dos acontecimentos não se restringia a essas colunas, muitas outras localidades apareciam dispersas em notas, notícias e anúncios, mesmo para aquelas urbes que já eram mencionadas nas seções gerais.

A estratégia de atuação do Diário e do Correio visava à ampliação do público leitor para além da cidade sede e buscava elementos agregadores das diversas localidades, pontos comuns a todos. Mouillaud (2002, p. 86) considera que o nome de um jornal identifica-o "por sua diferença com relação a todos os demais", ou seja, indica a identidade e a alteridade em relação a outros veículos, e no aspecto interno, acima de todos os enunciados, ele torna-se um envelope: "assegura a coerência e continuidade dos enunciados à maneira de uma pressuposição; constitui o princípio de uma espera, por parte do leitor, de certos enunciados". Articula e sustenta os títulos de matérias e guia o leitor nos contornos da produção impressa remetendo-a ao mundo com base em perfil editorial delineado por elementos compartilhados pelo universo do público e que se manifesta na série de textos, mencionando acontecimentos e temáticas referentes às diversas cidades. ${ }^{42}$

Desde o século XIX, jornais costumavam apresentar, no título, o recorte espacial de sua abrangência e representação jornalística, seguindo critérios político-administrativos, tais como, cidade, estado, país. ${ }^{43}$ Nessa perspectiva, seguindo uma tradição da imprensa, os jornalistas do Diário e do Correio incorporavam uma leitura dominante da territorialidade organizadora do novo oeste para definir a cobertura cotidiana e se tornarem representativos dos leitores. A área do âmbito da empresa ferroviária e a inserção das cidades na linha norteavam uma faceta de identidade regional, ${ }^{44}$ que possibilitava aos moradores e leitores 
se reconhecer por uma rede de significados comuns, como por exemplo, o sentimento de pertencimento a um lugar, a um território simbólico (GUATTARI, 1985). E os jornais identificaram a viabilidade de utilizar os elos de identidade circulantes, buscando representatividade entre seus leitores, ainda que fossem possiveis outros critérios de legitimidade.

Outros jornais com menor tiragem e circulação mais modesta, restritas às suas localidades, também se colocavam como representantes do território delimitado pelos eixos das ferrovias e definiam a localização considerando várias instâncias de abrangência, entre elas a posição em relação à linha. Em algumas situações, o nome da companhia aparecia como um ponto no espaço com recorte político-administrativo, entre outros: país, estado, cidade e linha. Por exemplo, O Penapolense, um periódico publicado em Penápolis, entre 1915 e 1939, também utilizou como subtítulo uma referência à Estrada de Ferro Noroeste do Brasil. A partir de 1930, era impresso abaixo do título "Órgão Oficial e de interesse do Município - Linha Noroeste" e, a partir de 1933, somente "L. Noroeste - Estado de S. Paulo".

O recurso ao recorte territorial da ferrovia como referência para definir o perfil editorial, seguindo os critérios de espacialidade e de identidade, perpassou jornais impressos de cidades posicionadas ao longo de linhas de outras companhias. Em localidades situadas à beira da Companhia Paulista de Estradas de Ferro, do trecho denominado de "Alta Paulista", vários veículos registraram a filiação ao território marcado pela ferrovia. Em Marília, o jornal Alto Cafezal registrava, abaixo do título, em 1928, o seu primeiro ano de existência, "Com circulação na Sorocabana, Paulista e Noroeste". Nos anos 1930, o Diário de Marília, marcava no cabeçalho "Órgão defensor dos interesses da Alta Paulista". Nos anos de 1940, o Jornal de Tupã destacava "Órgão de Circulação na Alta Paulista e Zona da Mata". ${ }^{45}$ Ainda nessa década, a partir de 1947, a Tribuna de Adamantina observava, no alto da primeira página, "Estado de São Paulo - Brasil - Linha Paulista". Na década de 1950, foram publicados em Adamantina Correio da Alta Paulista e Tribuna da Alta Paulista. Nos anos 1960, era lançado em Tupã o Jornal da Alta Paulista.

Fenômeno semelhante é identificado em cidades situadas ao longo das linhas da Estrada de Ferro Sorocabana. Em 1930, foi impresso em Botucatu, o Diário da Sorocabana, e em Presidente Prudente, nos anos 1950, os periódicos Correio da Sorocabana, que se manteve até os anos 1980, e Folha da Sorocabana. O Imparcial de Presidente Prudente estampava, na década de 1930, a localização: "Presidente Prudente, E. F Sorocabana (E. S. Paulo)". O Jornal de Assis publicou um texto sobre a importância para a região da ação do responsável pela instalação da via férrea ${ }^{46}$ e lançava mão de recurso semelhante ao Correio da Noroeste ao publicar matérias que intitulavam Assis como a "Capital da Sorocabana". ${ }^{47}$

Em cidades posicionadas à beira da Estrada de Ferro Araraquara a dinâmica era semeIhante. Em São José do Rio Preto circulava desde os anos 1920 o jornal A Notícia que, em 1933, incorporou o slogan "Diário Vespertino da Zona Araraquarense" e, a partir de 1936, passou ostentar "Diário Matutino da Zona Araraquarense" e publicou textos ufanistas colocando em destaque a cidade no território da Araraquarense. ${ }^{48}$ Outro periódico da mesma 
cidade publicou matérias que continham o nome da ferrovia, por exemplo, tratando da construção de uma ponte e sobre a importância dela para o progresso da "capital da Araraquarense". ${ }^{49}$ Por outro lado, o A Notícia também utilizava recurso ufanista sobre Mirassol inserindo-a no território da ferrovia. ${ }^{50}$ A Tribuna, veículo criado em 1942 em São José do Rio Preto, imprimia como slogan na década de 1950: "De Rio Preto para a Araraquarense e pela Araraquarense". Em 1955, passou a circular em São José do Rio Preto o Correio da Araraquarense. O Diário da Região, publicado em Jales desde os anos 1950, registrava abaixo do título "Um órgão da Araraquarense". Décadas depois, em 1972, as representações permaneciam, o Jornal de Jales noticiou a mobilização das autoridades para construção de uma rodovia ligando as cidades de Jales e Araçatuba. ${ }^{51} \mathrm{~A}$ matéria apresentava a demanda como necessidade que beneficiaria duas regiões de linhas férreas diferentes, Araraquarense e Noroeste.

Por fim, a representação espacial sob lógica ferroviária também foi reproduzida em trabalhos históricos diletantes e memorialísticos como forma de identificar o objeto pesquisado, por exemplo referente a "Alta Sorocabana" (GIOVANNETTI, 1943; SANTOS, 199-) e área de abrangência da Estrada de Ferro Noroeste do Brasil (ANDRADE, 1945). Trabalhos acadêmicos também recorreram ao mesmo recurso, por exemplo: "Alta Paulista" precisa a localização de área de influência de Marília, na dissertação de Sociologia - Capital da Alta Paulista. Uma História do município de Marília - de Balestriero (1984); delimita uma região com características econômicas próximas, na dissertação de História intitulada Incorporação da Nova Alta Paulista ao Setor Produtivo do Estado de São Paulo: município de Adamantina, 1937-1955, produzida por Silva (1989); a "Noroeste" localiza os atores históricos pesquisados, na dissertação de História sob o título Filhos de São Francisco e índios: ação missionária dos capuchinhos trentinos na noroeste paulista, 1890-1920; defendida por Gonçalves (1997).

\section{Considerações Finais}

O levantamento cronológico da formação e transformação urbana e do amplo território permite enunciar que "oeste de São Paulo" é um construto técnico, político e cultural, adquiriu diferentes conformações, no espaço e no tempo, e contribuiu para a elaboração de identidades locais e regionais. A ferrovia desempenhou papel decisivo na configuração dos novos espaços e foi alçada à chave-interpretativa de leitura do "novo oeste" de São Paulo nas primeiras décadas do século XX. E, nessa perspectiva, as cidades da região não eram pensadas isoladamente, inseriam-se em redes de cidades perpassadas por linhas ferroviárias que cruzavam a região de leste para oeste. No caso do âmbito da "zona noroeste", há dominante associação entre as cidades e a Estrada de Ferro Noroeste do Brasil por pelo menos três elementos: a) pela dinâmica de surgimento, a construção da linha interferiu na origem das unidades urbanas; b) até os anos 1950, a ferrovia era o principal meio de comunicação e transporte entre elas e com a capital do Estado; c) o estreito vínculo formado entre as urbes pela unidade ferroviária permitiu uma identidade agregadora entre as 
localidades, costurada pelo sentido interpretativo de ocupação e formação, a despeito de eventuais disputas entre elas.

Na década de 1920, foram surgindo estradas para ligar o centro urbano às fazendas e patrimônios, criar alternativa viária entre cidades à beira da linha, mas também começaram a surgir rotas entre novas localidades e pequenos assentamentos no eixo norte-sul, ou seja, longitudinal às linhas férreas. E a cada década as estradas adquiriam mais importância, mas até em torno de 1960 essas vias não eram asfaltadas, o trem predominava como meio de transporte para grandes cargas e longas distâncias e a ferrovia ainda dominava as representações de organização espacial.

Segundo as principais representações da região circulantes nas primeiras décadas do século XX, o passado não deveria existir, ele era negado por corresponder ao tempo da natureza. Os tempos cognosciveis eram o presente e o futuro em perspectiva linear, expressando a manifestação do "progresso" e da "civilização". A vegetação, os índios e a paisagem precisavam ser alterados e controlados visando à inserção no sistema produtivo de mercado, ao desenho de novas paisagens rurais e urbanas, de novas sociabilidades e hábitos cotidianos regidos pelas lógicas dos grandes centros, ainda que muitas vezes se restringissem a jogos de cena. A resistência indígena contra as novas territorialidades foi derrotada, a perspectiva de trabalhadores ferroviários e urbanos, bem como de segmentos populares moviam-se em outras direções e as memórias e histórias dominantes as silenciaram embora ainda existam ecos em documentação remanescente.

As representações dominantes seguindo a lógica do tempo supostamente contínuo focavam no pioneirismo desbravador do paulista, produtor da pujança econômica da região e do Estado. A efervescência econômica tendia a materializar-se na unidade urbana, em detrimento do silêncio em relação ao campo que, por sua vez, se articulava às outras ao longo da linha e formavam a zona ferroviária entendida como componente da dinâmica estadual. Essa representação entreabre a interpretação de que as regiões ou zonas não eram entendidas como isoladas, pois as suas temporalidades inseriam-se na do estado de São Paulo (BRESCIANI, 1999) e em lógicas interpretativas mais amplas e diversos textos em diferentes suportes contribuíram para elaboração, difusão e consolidação dessas representações, incluindo alguns de origem acadêmica.

\section{Referências}

ABREU, D. S. Comunicações entre o sul de Mato Grosso e o sudoeste de São Paulo. O comércio de gado. Revista de História, São Paulo, n. 105, p. 191-214, 1976.

AMADO, J. Região, Sertão, Nação. Revista de Estudos Históricos, Rio de Janeiro, v. 8, n. 15, p. 145-153, 1995. 
ANDRADE, E. L. Os Sertões da Noroeste. [S.I.]: [s.n.], [1945?].

ARRUDA, G. Cidades e Sertões: Entre a história e a memória. Bauru: Edusc, 2000.

AZEVEDO, F. de. Um trem corre para oeste: Estudo sobre a Noroeste e seu papel no sistema de viação nacional. 2. ed. São Paulo: Melhoramentos, 1950.

BAlestriero, G. E. Capital da Alta Paulista: Uma história do Município de Marília. 1984. Dissertação (Mestrado em Sociologia) - Instituto de Filosofia e Ciências Humanas, Universidade Estadual de Campinas, Campinas, 1984.

BASTOS, I. A. Sertão Noroeste: O poder municipal na República Velha. Bauru: Edipro, 2000.

BEOZZO, J. O. Noroeste Paulista: aspectos demográficos. Revista de Cultura Vozes, Petrópolis, v. 63, n. 9, p. 771-87, set. 1969.

BOURDIEU, P. A identidade e a Representação: elementos para uma reflexão crítica sobre a ideia de região. In: BOURDIEU, P. O Poder Simbólico. 8. ed. Rio de Janeiro: Bertrand Brasil, 2005. p. 107-132.

BRESCIANI, M. S. Imagens de São Paulo: estética e cidadania. In: FERREIRA, A. C; LUCA, T. R.; IOKOI, Z. G. (Orgs.). Encontros com a História: Percursos históricos e historiográficos de São Paulo. São Paulo: Editora UNESP, 1999. p. 11-45.

CASTRO, M. I. M. O Preço do Progresso: A Construção da Estrada de Ferro Noroeste do Brasil (1905-1914). 1993. Dissertação (Mestrado em História) - Instituto de Filosofia e Ciências Humanas, Universidade Estadual de Campinas, Campinas, 1993.

CAVENAGHI, A. J. Olhos do Barão, Boca do Sertão: um apequena história da fotografia e da cartografia no noroeste do território paulista (a segunda metade do século XIX ao início do século XX). 2004. Tese (Doutorado em História) - Faculdade de Filosofia, Letras e Ciências Humanas, Universidade de São Paulo, São Paulo, 2004.

CHARTIER, R. A História Cultural: entre práticas e representações. Lisboa: Difel, 1990.

COBRA, A. N. Recanto do Sertão Paulista. São Paulo: HENNIES \& Cia, 1943.

COMISSÃO GEOGRÁFICA E GEOLÓGICA DO ESTADO DE S. PAULO. Exploração dos Rios Feio e Aguapehy. (extremo sertão do estado). São Paulo: Typographia Brazil de Carlos Gerke \& Rothshild Cia., 1906. 
Peixe. (extremo sertão do estado). 2. ed. São Paulo: Typographia Brazil de Rothshild Cia., 1913.

COMISSÃO GEOGRÁFICA E GEOLÓGICA DO ESTADO DE S. PAULO. Exploração do Rio Tietê. (Barra do Rio Jacaré-Guassú ao Rio Paraná). 3. ed. São Paulo: Typographia Brazil de Rothshild \& Cia., 1930.

CONSTANTINO, N. R. T. A Estrutura agrária na formação do tecido urbano das cidades do oeste paulista. In: SALGADO, I.; BERTONI, A. (Orgs.). Da construção do Território ao Planejamento das Cidades: competências técnicas e saberes profissionais na Europa e nas Américas (1850-1930). São Carlos: RIMa, 2010. p. 35-49.

COSTA, L. F. de C. O Caminho de São Bento de Araraquara. In: ALMEIDA, A. M. de; ZILLY, B.; LIMA, E. N. (Orgs.). De sertões, desertos e espaços incivilizados. Rio de Janeiro: Mauad/ FAPERJ, 2001. p.111-130.

CUCHE, D. Cultura e Identidade. In: UCHE, D. A Noção de Cultura nas Ciências Sociais. Bauru: Edusc, 1999. p. 175-202.

DI CREDDO, M. do C. S. A Construção de Estradas na Política de Povoamento do Vale do Paranapanema. O picadão Botucatu-Avanhandava. História (São Paulo), Assis/Franca, v. 12, p. 147-54, 1993.

ENOKIBARA, M. Praças e jardins no oeste paulista - a formação e transformação do espaço público com a introdução da ferrovia. In: SALGADO, I.; BERTONI, A. (Orgs.). Da construção do Território ao Planejamento das Cidades: competências técnicas e saberes profissionais na Europa e nas Américas (1850-1930). São Carlos: RIMa, 2010. p. 189-207.

ERCILLA, A. M. de; PINHEIRO, B. Estado de São Paulo: Zona Noroeste. São Paulo: Propaganda Pan-americana, 1928.

FERRAZ, B. Cidades Vivas. São Paulo: Monteiro Lobato \& Comp. Editores, 1924.

FERROVIA. Edição Comemorativa do 90aniversário da Companhia Paulista de Estrada de Ferro. Ano XXIV, n. 279, 1958-1959.

FIGUEIREDO, J. L. A Noroeste do Brasil e a Brasil Bolívia. Rio de Janeiro: José Olympio, 1950.

FIGUEIRÔA, S. F. de M. Modernos bandeirantes: a Comissão Geográfica e Geológica de São Paulo e a exploração científica do território paulista (1886-1931). 1987. Dissertação (Mestrado em História) - Faculdade de Filosofia, Letras e Ciências Humanas, Universidade de São Paulo, São Paulo, 1987. 
FOUCAULT, M. Sobre a Geografia. In: FOUCAULT, M. Microfísica do Poder. 3. ed. Rio de Janeiro: Graal, 1982. p. 153-65.

FRANÇA, A. A Marcha do café e as frentes pioneiras. Rio de Janeiro: Conselho Nacional de Geografia, 1960.

GHIRARDELLO, N. À Beira da Linha: Formações urbanas da Noroeste Paulista. São Paulo: Editora da UNESP, 2002.

GIESBRECHT, R. M. Um dia o trem passou por aqui. São Paulo: [s.n.], [2001?].

GIOVANNETTTI, B. Esboço Histórico da Alta Sorocabana. São Paulo: Revista dos Tribunais, 1943.

GODOY, J. F. de. A Província de S. Paulo: Trabalho Estatístico, Histórico e Noticioso. Apresentação de Tânia Regina de Luca. São Paulo: Imprensa Oficial do Estado de São Paulo; FUNDAP, 2007. Edição Fac-símile.

GONÇALVES, R. F. Filhos de São Francisco e índios: ação missionária dos capuchinhos trentinos na noroeste paulista (1890-1920). 1997. Dissertação (Mestrado em História) Faculdade de Ciências e Letras, Universidade Estadual Paulista, Assis, 1997.

GRANDI, D. F.; CARVALHO, G. A tomada do trem: a greve de 1914 dos ferroviários da Noroeste. In: JORNADAS DE HISTORIA ECONÓMICA, XXI., 2008, Caseros (Buenos Aires). Anais... Caseros (Buenos Aires): Asociación Argentina de Historia Económica/UNTREF, 2008. Disponível em: <http://xxijhe.fahce.unlp.edu.ar>. Acesso em: 06 jun. 2016.

GUATTARI, F. Espaço e Poder: a criação de territórios na cidade. Espaço e Debates, São Paulo, n. 16, p. 109-129, 1985.

HARDMAN, F. F. Trem Fantasma: A Modernidade na Selva. São Paulo: Companhia das Letras, 1991.

HOLANDA, S. B. de. Monções. 3. ed. São Paulo: Brasiliense, 1990.

INSTITUTO BRASILEIRO DE GEOGRAFIA E ESTATÍSTICA - IBGE. Enciclopédia dos Municípios Brasileiros. Rio de Janeiro: IBGE, 1957.

LIMA, J. F. T. de. Ocupação da Terra e Destruição dos Índios na Região de Bauru. 1978. Dissertação (Mestrado em História) - Faculdade de Filosofia, Ciências e Letras, Universidade de São Paulo, São Paulo, 1978.

LIMA, S. L. L. O Oeste Paulista e a República. São Paulo: Vértice, 1986. 
LOSNAK, C. J. Obras Impressas: um recorte do pensamento das elites paulistas das primeiras décadas do século XX. In: COELHO, J. G.; VICENTE, M. M. (Orgs.). Pensamento e Linguagem: subjetividade, comunicação e arte. São Paulo: Cultura Acadêmica, 2008. p. 235-254.

LOSNAK, C. J. O Oeste de São Paulo como territórios em fluxos modernos. In: SALGADO, I.; BERTONI, A. (Orgs.). Da construção do Território ao Planejamento das Cidades: competências técnicas e saberes profissionais na Europa e nas Américas (1850-1930). São Carlos, SP: RIMa, 2010. p. 91-100.

LOVE, J. A Locomotiva: São Paulo na Federação Brasileira (1889-1937). Rio de Janeiro: Paz e Terra, 1982.

MANFREDI NETO, P. O Trem da Morte: O imaginário do progresso na noroeste (19051930). 1995. Dissertação (Mestrado em Sociologia) - Faculdade de Filosofia, Letras e Ciências Humanas, Universidade de São Paulo, São Paulo, 1995.

MARTINS, J. de S. Frente Pioneira: contribuição para uma caracterização sociológica. Estudos Históricos, Marília, v. 10, p. 33-41, 1971.

MARTINS, J. de S. Introdução. In: MARTINS, J. de S. Fronteira: a degradação do Outro nos confins do humano. São Paulo: Contexto, 2009. p. 9-21.

MARTINS, O. Cel. Manoel Bento da Cruz: Apontamentos biográficos. Araçatuba: NOROGRAF, 1968.

MATOS, O. N. Café e Ferrovias: A evolução ferroviária de São Paulo e o desenvolvimento da cultura cafeeira. Campinas: Pontes, 1990.

MOMESSO, L. José Duarte: um maquinista da história. São Paulo: Oito de Março, 1988.

MONBEIG, P. Pioneiros e Fazendeiros de São Paulo. São Paulo: Hucitec-Polis, 1984.

MORATELLI, T. Os trabalhadores da construção da Estrada de Ferro Noroeste do Brasil: Experiências Operárias em um sistema de trabalho de grande empreitada (São Paulo e Mato Grosso, 1905-1914). 2009. Dissertação (Mestrado em História) - Instituto de Filosofia e Ciências Humanas, Universidade Estadual de Campinas, Campinas, 2009.

MOREIRA, M. e F. S. A organização do processo de trabalho: sua dimensão política na Estrada de Ferro Sorocabana (1920-1940). 1989. Dissertação (Mestrado em História) Faculdade de Ciências e Letras, Universidade Estadual Paulista, Assis, 1989.

MOUILLAUD, M. Informação Local: espaço público local e suas mediações. In: 
MOUILLAUD, M.; PORTO, S. D. O Jornal: da forma ao sentido. Brasília: Editora UNB, 2002. p. $431-48$.

MOUILLAUD, M. O Nome do Jornal. In: MOUILLAUD, M.; PORTO, S. D. O Jornal: da forma ao sentido. Brasília: Editora UNB, 2002. p. 85-98.

NAXARA, M. R. C. Estrangeiro em sua própria terra: representações do brasileiro 1870/1920. São Paulo: Annablume, 1998.

NEIVA, A. Daqui e de Longe: crônicas nacionais de viagem. São Paulo: Comp. Melhoramentos de São Paulo, [1927].

NEVES, C. das. História da Estrada de Ferro Noroeste do Brasil. Bauru: Tipografias e Livrarias Brasil S/A, 1958.

NOVA DIVISÃO TERRITORIAL DO BRASIL. Origem dos Municípios do Estado de São Paulo. Qüinqüênio 1955/1958. São Paulo: Editor Marcio Bagueira Leal, 1955.

OLIVEIRA, L. L. A Conquista do Espaço: sertão e fronteira no pensamento brasileiro. História, Ciências, Saúde - Manguinhos, Rio de Janeiro, v. 5, supl. 0, p. 195-215, jul. 1998.

PELEGRINA, G. R. Memórias de um ferroviário. Bauru: EDUSC, 2000.

PINHEIRO, N. S. Os Nômades. Etnohistória Kaingang e seu contexto: São Paulo - 1850 a 1912. 1992. Dissertação (Mestrado em História) - Faculdade de Ciências e Letras, Universidade Estadual Paulista, Assis, 1992.

PINHEIRO, N. S. Vanuíre: Conquista, Colonização e Indigenismo: oeste paulista, 19121967. 1999. 293 f. Tese (Doutorado em História) - Faculdade de Ciências e Letras, Universidade Estadual Paulista, Assis, 1999.

QUEIROZ, M. I. P. de. Ufanismo Paulista: vicissitudes de um imaginário. Revista USP, São Paulo, n. 13, p. 78-87, 1991.

QUEIROZ, P. R. C. As Curvas do Trem e os Meandros do Poder: O nascimento da estrada de ferro Noroeste do Brasil (1904-1908). 1992. Dissertação (Mestrado em História) Faculdade de Ciências e Letras, Universidade Estadual Paulista, Assis, 1992.

QUEIROZ, P. R. C. Uma ferrovia entre dois mundos: a E. F. Noroeste do Brasil na primeira metade do século 20. Bauru: EDUSC; Campo Grande: Ed. UFMS, 2004.

ROMANELLO, J. L. Imagens e Visões do Paraíso no Oeste Paulista: Um estudo do imaginário regional. 1998. Dissertação (Mestrado em História) - Faculdade de Ciências e 
Letras, Universidade Estadual Paulista, Assis, 1998.

SAES, F. A. M de. As Ferrovias de São Paulo, 1870-1940: Expansão e declínio do transporte ferroviário em São Paulo. São Paulo: HUCITEC; Brasília: INL, 1981.

SANTOS, A. P. dos. Terrenos Desconhecidos: Solos historio-gráficos sobre uma mesma base documental. 1992. Dissertação (Mestrado em História) - Faculdade de Ciências e Letras, Universidade Estadual Paulista, Assis, 1992.

SANTOS, M. Por uma geografia nova. 4. ed. São Paulo: HUCITEC, 1996.

SANTOS, W. Diagnóstico histórico e econômico da região Alta Sorocabana. Presidente Prudente, SP: [s.n.], [199-].

SCHMIDT, C. Diário de uma viagem pelo sertão paulista de São Paulo, realizada em 1904. Anais do Museu Paulista. São Paulo, T. XV, p. 337-458, 1961.

SEVCENKO, N. Literatura como Missão: Tensões sociais e criação cultural na Primeira República. São Paulo: Brasiliense, 1983.

SILVA, R. G. da. Incorporação da Nova Alta Paulista ao Setor Produtivo do Estado de São Paulo: município de Adamantina (1937-1955). 1989. Dissertação (Mestrado em História) Instituto de Letras, História e Psicologia, Universidade Estadual Paulista, Assis, 1989.

SLENES, R. Senhores e subalternos no oeste paulista. In: ALENCASTRO, L. F. (Org.). História da Vida Privada no Brasil. São Paulo: Companhia das Letras, 1997. p. 233-290. (Império: a corte e a modernidade nacional. v. 2).

\section{Fontes Jornalísticas}

A FOLHA. São José do Rio Preto. 1941-1943.

A NOTíCIA. São José do Rio Preto, 1930-1940.

DIÁRIO DA NOROESTE. Bauru, 1925-1930.

JORNAL DE ASSIS. Assis, 1934.

JORNAL DE JALES. Jales, 1971-1973.

O BAURU. Bauru, 1906-1924. 
O BAURU. Bauru. Bauru, 13 jul. 1922. p. 1.

\section{Notas}

1 O grupo tinha por tema-título "Saberes técnicos e teóricos na configuração e reconfiguração das cidades formadas com a abertura de zonas pioneiras do oeste do estado de São Paulo" e pertencia ao Projeto Temático "Saberes Eruditos e Técnicos na Configuração e Reconfiguração do Espaço Urbano - estado de São Paulo, séculos XIX e XX", coordenado por Maria Stella Bresciani.

2 Outro exemplo é o livro O Oeste Paulista e a República (LIMA, 1986).

3 A delimitação clara do território paulista no âmbito político-administrativo foi definida no decorrer do século XIX baseada em articulações políticas com Minas Gerais e Paraná para delimitação das fronteiras, apoiada por trabalhos cartográficos e investigações de engenheiros (CAVENAGHI, 2004; SANTOS, 1992; FIGUEIRÔA, 1987).

4 Holanda (1990, p. 42) afirma que, no século XVIII, Piracicaba e Porto Feliz eram boca de sertão.

5 Quando, em 1904, o engenheiro Cornélio Schmidt fez uma viagem de exploração por trilhas passando pela vila de São José do Rio Preto, seguindo para a área onde hoje está situada a cidade de Jales, depois atravessando o Rio Tietê no salto do Avanhandava, passando por Novo Horizonte, Bauru, Campos Novos e atingindo a região da atual Presidente Prudente, ele observou os moradores do "sertão" e descreveu-os quase sempre como destituídos de "civilização" (SCHMIDT, 1961; ARRUDA, 2000; LOSNAK, 2010).

6 Algumas datas de formação de cidades ajudam a perceber o movimento de transformação do território por meio da cronologia do processo de crescimento e complexização das localidades. Botucatu torna-se vila em 1855 e em 1876 é elevada à categoria de cidade; São Domingos tornou-se freguesia em 1858, foi transferida para Santa Bárbara do Rio Pardo em 1874 que, por sua vez foi elevada a município em 1876; Santa Cruz do Rio Pardo tornou-se freguesia em 1872, vila em 1876 e cidade em 1896; Lençóis Paulista tornou-se freguesia em 1858, município em 1865 e comarca em 1877; Campos Novos tornou-se distrito de paz de Santa Cruz do Rio Pardo em 1880, em 1885, município, e comarca em 1892; Jaú tornou-se freguesia em 1859, vila em 1866 e município em 1889; Araraquara tornou-se distrito em 1817 e município em 1832; Jaboticabal tornou-se freguesia em 1857, vila em 1867, em 1868 foi instalada a Câmara e a Comarca, em 1887; São José do Rio Preto foi elevada a freguesia em 1879, a municipio em 1894 e a Comarca em 1906 (INSTITUTO BRASILEIRO DE GEOGRAFIA E ESTATÍSTICA, 1957; NOVA DIVISÃO TERRITORIAL DO BRASIL, 1955).

7 Parte dessa lacuna foi suprida pelas expedições da Comissão Geológica e Geográfica de São Paulo que percorreram os principais rios: Itapetininga e Paranapanema, em 1886; Sorocaba, em 1887; do Peixe, em 1905 e 1906; Feio e Aguapeí, em 1905; Tietê, em 1905; Paraná, em 1905; Ribeira do Iguape, em 1906; Grande, em 1910. Essas expedições mapearam os rios observando avaliando a navegabilidade e observando relevo, solo, vegetação e população (COMISSÃO GEOGRÁFICA E GEOLÓGICA DO ESTADO DE S. PAULO, 1906, 1913, 1930). As expressões "sertão desconhecido", "terrenos desconhecidos" foram utilizadas por muitos autores, em diversos tipos de textos, tanto no século XIX como no XX (AMADO, 1995; OLIVEIRA, 1998; ARRUDA, 2000).

8 Martins (1971, p. 37-40) propõe o conceito de "frente pioneira" para esse fenômeno: o momento de instalação de empreendimentos econômicos: "empresas imobiliárias, ferroviárias, comerciais, bancárias, etc., e que loteiam terras, transportam mercadorias, compram e vendem, financiam a produção e o comércio". Ela está baseada na compra e propriedade privada da terra, é "resultado direto da necessidade de reprodução da sociedade capitalista"; e seria a "expressão limite do capitalismo no campo".

9 Essa área tem certa aproximação com a formação geológica que Monbeig (1984) denominou de Planalto Ocidental Paulista. Formação geológica que corta todo o estado de norte a sul, é iniciada em elevações abruptas, como a cuesta de Botucatu, é cortada por seis rios (de sul para norte, há o rio Paranapanema, o Rio do Peixe, o rio Feio-Aguapei, o rio Tietê, o rio São José dos Dourados e o rio Grande) que rumam para o terreno em declínio chegando ao rio Paraná. Entre os rios existem áreas mais altas, denominadas pelo geógrafo de espigões, onde as ferrovias foram instaladas.

10 Trabalhos acadêmicos (PINHEIRO, 1999; ROMANELLO, 1998) do passado recente utilizaram oeste para delimitar espacialmente a dinâmica de seu objeto.

11 Alguns municípios mais recentes e próximos ao rio Paraná incorporaram em seu nome a inserção no oeste: Aparecida do Oeste (1964), Palmeira do Oeste (1959), Estrela do Oeste (1949), Santa Clara do Oeste (1964), Santa Rita do Oeste (1964), Guarani do Oeste (1959). 
12 Eventualmente, pode ocorrer desencontro de datas elencadas em decorrências dos critérios de datação, algumas fontes citam o ano de implantação dos trilhos, outras mencionam a inauguração oficial do trecho.

13 Chegou a Agudos em 1903, Piratininga em 1905, e Bauru em 1910, atingiu Marília em 1928, Pompéia em 1935, Tupã em 1941, Adamantina em 1950, Dracena em 1959 e Panorama em 1962 (FERROVIA, 1958-1959; GIESBRECHT, 2001?; INSTITUTO BRASILEIRO DE GEOGRAFIA E ESTATÍSTICA, 1957).

14 De capital privado, inaugurou o trecho São Paulo-Sorocaba em 1875. Problemas econômicos sucessivos levaram a empresa a passar para o controle do governo federal, em 1902, para o governo estadual, em 1905, e para um grupo estrangeiro, em 1907. Em 1919, ela foi retomada pelo governo de São Paulo e tornou-se estatal. O ramal que partia de Botucatu chegou a Bauru em 1905. A linha-tronco continuou de Botucatu e chegou a Avaré, em 1896, a Ourinhos, em 1908, a Assis em, 1914, a Presidente Prudente, em 1919 e ao rio Paraná, em 1922 (MOREIRA, 1989; GIESBRECHT, 2001?).

15 Foi criada em 1895 e as obras iniciadas em 1896. Problemas administrativos levaram-na à falência, em 1916 a massa falida foi comprada por um grupo norte-americano. Logo depois, em 1919, o governo do Estado desapropriou-a tornando-a estatal. O trecho Araraquara-Matão foi concluído em 1898, continuou até São José do Rio Preto em 1912, até Bálsamo em 1941, Votuporanga em 1945, Fernandópolis em 1949, Jales em 1951, Santa Fé do Sul e Rubinéia em 1952 (GIESBRECHT, 2001?; INSTITUTO BRASILEIRO DE GEOGRAFIA E ESTATISTICA, 1957).

16 Passou por Avaí em 1906, Lins em 1907, Penápolis e Araçatuba em 1908 (NEVES, 1958; QUEIROZ, 2004).

17 Em trabalho posterior, Martins (2009, p. 9-21) atualiza a discussão em torno das áreas "pioneiras" com a categoria "fronteira", entendidas como o "ponto limite de territórios que se redefinem continuamente, disputados de diferentes modos por diferentes grupos humanos". Uma das disputas presentes nessa linha é sobre a separação entre "cultura e natureza, o homem do animal, quem é humano e quem não o é" (MARTINS, 2009, p. 10). Um lugar de conflito entre homens e instituições, de "conflitos e dificuldades próprios da constituição do humano no encontro de sociedades que vivem no seu limite e no limiar da história" (MARTINS, 2009, p. 10). Nessa perspectiva, fronteira não se resume ao recorte geográfico, há a "fronteira da civilização (demarcada pela barbárie que nela se oculta), fronteira espacial, fronteiras de culturas e visões de mundo, fronteiras de etnias, fronteira da história e da historicidade do homem. E, sobretudo, fronteira do humano" (MARTINS, 2009, p. 110). O autor defende a abordagem sociológica como caminho para reconhecer a figura central da fronteira, a vítima (e não o pioneiro), por meio da valorização da alteridade e da particular visibilidade do outro. Limitamo-nos, aqui, a registrar a crítica do autor a um tema importante, mas que não será abordado neste artigo. Para ele, as abordagens tradicionais centravam-se na figura imaginária e mítica do pioneiro e, com isso, não reconheciam o aspecto trágico da fronteira com o confronto e genocídio de etnias e o conflito de classes.

18 Aponta também para interesses políticos de mato-grossenses e interesses econômicos em ligar a Noroeste às linhas da Companhia Paulista de Estradas de Ferro e às da Estrada de Ferro Sorocabana. Essas perspectivas sinalizavam a necessidade de ampliar a rede de transporte e comunicação estendendo o território existente para áreas ainda desconectadas da produção capitalista.

19 A exploração do Rio Feio-Aguapeí ocorreu em 1905 quando a Estrada Ferro Noroeste do Brasil já estava em construção. Ela foi iniciada e interrompida em 1905 em razão de um ataque indígena. No ano seguinte, foi retomada e concluída. Para Figueirôa (1987), as expedições visavam não apenas identificar a navegabilidade dos rios, mas também reconhecer as riquezas naturais e as potencialidades econômicas dessas áreas. Em outra perspectiva, era a oficialização, da parte do Estado, da autoridade de conhecimento e de domínio de tudo que estava ali, homem e natureza.

20 Até Penápolis já existiam esparsos agrupamentos de moradores e algumas fazendas de café antes do início da construção da via. As principais cidades surgidas a partir da instalação das estações e voltadas para a produção cafeeira foram Avaí, Presidente Alves, Cafelândia, Lins, Avanhandava, Penápolis. Entre Bauru e Lins, predominavam as grandes fazendas de café, no trecho entre Penápolis, Promissão, Birigui e Araçatuba a formação do território baseou-se no comércio de terra por uma grande empresa, "The San Paulo, Land, Lumber \& Colonization", propiciando a pequena propriedade, embora em todas as cidades a malha urbana tenha sido desdobrada de grandes glebas e pertencentes a poderosos locais (ERCILLA; PINHEIRO, 1928; ANDRADE, 1945?; MARTINS, 1968). 21 Essa característica esteve presente no processo de escolha do roteiro de assentamento da linha e de instalação de estações. Os grandes proprietários interferiram nas decisões técnicas e demandaram trechos e instalações ferroviárias em suas fazendas, tais como o coronel Joaquim de Toledo Piza, no trecho entre Bauru e Pirajuí, e Manoel Bento da Cruz, no trecho entre Promissão e Araçatuba (ERCILLA; PINHEIRO, 1928; MARTINS, 1968). 22 O primeiro trajeto inicial da ferrovia entre Araçatuba e o rio Paraná foi ao longo do curso do rio Tietê (QUEIROZ, 
2004; NEVES, 1958).

23 Guararapes (chegada dos trilhos em 1929, distrito em 1934 e município em 1937), Rubiácea (chegada dos trilhos em 1930, distrito em 1944 e município em 1949), Bento de Abreu (chegada da linha em 1930, distrito em 1933 e município em 1949), Valparaiso (chegada da linha em 1932, distrito em 1934 e município em 1937), Lavinia (chegada dos trilhos em 1935, distrito em 1938 e município em 1945), Mirandópolis (chegadas dos trilhos em 1935, distrito em 1937 e município em 1945), Guaraçaí (chegada dos trilhos em 1935, distrito, em 1938, e município, em 1949), Murutinga do Sul (inauguração da estação em 1937, distrito em 1944 e município em 1954), Andradina (inauguração da estação e distrito em 1937, município em 1939), Castilho (inauguração da estação em 1937, distrito em 1944 e município em 1953). Inicialmente, a principal atividade econômica desse trecho também era o café, mas a partir dos anos 1930 outros produtos passam a predominar, tais como o gado em Andradina (INSTITUTO BRASILEIRO DE GEOGRAFIA E ESTATISTICA, 1957; NOVA DIVISÃO TERRITORIAL DO BRASIL, 1955).

24 Estrada de Ferro Transcontinental. A comissão de estudos regressa da Bolívia (DIÁRIO DA NOROESTE, 11 dez. 1925. p. 2). Azevedo (1950) informa que Bousquet percorreu a Bolivia entre 1922 e 1924 em estudos para avaliar o melhor traçado nas áreas brasileira e boliviana.

25 A ferrovia Madeira-Mamoré foi construída para cumprir o contrato. Em 1937 (AZEVEDO, 1950), teria sido assinado o último acordo para o Brasil construir o trecho Corumbá-Santa Cruz de la Sierra.

26 As questões econômicas e políticas vinculadas à Bolivia, Paraguai e Argentina são detalhadamente analisadas por Queiroz (2004, p. 111-187).

27 Ligando dois Oceanos (DIÁRIO DA NOROESTE, 15 jan. 1926, p. 1).

28 O estudo teria começado em 1922 ou em 1924 (as informações são conflitantes) coordenado pelo Engenheiro Bousquet e várias equipes que percorreram trechos diferentes para mapear possiveis trajetos. $\mathrm{O}$ jornal detalha que havia a participação de profissionais bolivianos. Queiroz (2004, p. 162) informa que a proposta de Bousquet era ligar a linha de Porto Esperança diretamente à cidade de Sant'Ana, na Bolivia, enquanto que as lideranças de Corumbá eram contra. Em fevereiro de 1926, o Diário da Noroeste reproduz uma entrevista com o economista de Corumbá, Barros Maciel que defende o trajeto Porto Esperança-Corumbá-Porto Suares-Santa Cruz de la Sierra como o melhor (A Estrada de Ferro Santos à Arica) (DIÁRIO DA NOROESTE, 3 fev. 1926, p. 1.)

29 A ligação direta com o Oceano Pacífico não se concretizou. Queiroz (2004) apresenta a existência de continuidade de acordos e projetos entre o Brasil e a Bolivia, mas nada teria se efetivado nesse periodo, apesar do interesse brasileiro em canalizar o escoamento da produção boliviana e competir com as ferrovias argentinas. Nos anos 1950 a discussão persistia e o engenheiro e diretor da NOB fez uma conferência em São Paulo, depois editada em livro, relatando sua administração, avaliando as condições da companhia e apontando para a necessidade de efetivar a conexão tão propalada décadas antes (FIGUEIREDO, 1950).

30 Azevedo (1950) comenta que no século XIX vários projetos foram feitos para interligar os países da região sul, o tema foi objeto de inúmeros debates por engenheiros e políticos, um dos principais projetos elaborados foi o de André Rebouças em 1890. Queiroz (2004, p. 160) informa que já em 1871 havia proposta de ligar Curitiba ao sul de Mato Grosso.

31 Dr. Machado de Melo (O BAURU, 16 fev. 1908, p. 2); Dr. Eugenio Lafon (O BAURU, 16 fev. 1908, p. 3); Noroeste do Brasil (O BAURU, 16 ago. 1908, p. 1).

32 O BAURU. Bauru. Bauru, 13 jul. 1922, p. 1.

$33 \mathrm{Em}$ texto discutindo algumas mudanças de nomes da direção de construção e apostando na eficiência das obras, o redator do O Baurú conclui enfatizando os objetivos projetados para a ferrovia. "Seja porém, como for, os nossos votos são para que possamos em breve ver a Noroeste transpondo os grandes sertões deste Estado, e também levando a civilização aos Estados limitrofes e facilitando acesso às fronteiras dos países vizinhos, que é precisamente o seu objetivo". Noroeste do Brasil. (O BAURU, 16 ago. 1908, p. 1). Textos semelhantes estão em: Noroeste do Brasil (O BAURU, 16 fev. 1908, p. 2); De Avanhandava (O BAURU, 27 out. 1907, p. 1); Pelo Município (O BAURU, 12 jul. 1908, p. 1); De Viagem (O BAURU, 5 mar. 1922, p. 1).

34 Ultima hora - ataque dos índios (O BAURU, 28 jul. 1907. p. 2); Assalto de índios (O BAURU, 2 ago. 1908, p. 2); Engenharia (O BAURU, 16 ago. 1908, p. 2); NERO, Os Coroados (O BAURU, 03 abr. 1910, p. 1).

35 Noroeste do Brasil (O BAURU, 16 ago. 1908, p. 1).

36 Assalto de índios (O BAURU, 20 mar. 1910, p. 1).

37 Os Coroados (O BAURU, 03 abr. 1910, p. 1).

38 Lima (1978) defende que o principal conflito não ocorreu com a ferrovia e sim com os grandes proprietários de terras.

39 Além de Lima (1978), Pinheiro (1992, 1999) pesquisou sobre os conflitos com os Caingangues e a destruição 
daquela sociedade.

40 No caso específico da Noroeste, há uma particularidade, a denominação torna-se autônoma e parece definir uma área que estaria supostamente à noroeste do Estado, o que é um erro pois ela está na linha central no sentido oeste. Apesar disso, a autonomia da palavra Noroeste predominou, identificando um território, aparentemente descolado do nome da ferrovia, foi sendo impresso nos títulos de livros, revistas, nomeando empresas e lugares, tornando-se temas de obras de jornalistas, memorialistas e trabalhos acadêmicos até quase o final do século XX. 41 O Congresso Regional da Noroeste (DIÁRIO DA NOROESTE, 15 abr. 1926, p. 1).

42 Em outro texto Mouillaud (2002, p. 431-48) articula mídia e espaço e afirma que na França após a Revolução Francesa a imprensa escrita seguiu divisões políticas e administrativas ligadas à "gestão do Estado-Nação" e também houve recorte orientado pelas circunscrições diocesanas.

43 Vários jornais paulistas utilizaram esses critérios, tais como O Estado de S. Paulo, Folha de S. Paulo, Jornal do Brasil, A Província de S. Paulo, Correio Paulistano, O Commércio de S. Paulo, Diário de S. Paulo.

44 Identidade aqui é usada como uma construção que se dá no interior do social, determina a posição dos agentes, de suas representações e escolhas, ao mesmo tempo em que é produto delas. A identidade existe sempre em relação à outra identidade, "a identificação acompanha a diferenciação", é inclusão e exclusão. Há diferenças entre identidades social e cultural, entre indivíduo, grupo social e grupo étnico. Aqui, trata-se de identidade social que é cultural, mas não étnica (CUCHE, 1999).

45 Região mais ocidental e além de Tupã para onde rumavam os trilhos da Companhia Paulista.

46 A Zona da Alta Sorocabana e o Comendador José Giorgi (JORNAL DE ASSIS, 18/10/1934, p. 1).

47 Por exemplo, "Assis - Capital da Alta Sorocabana" (JORNAL DE ASSIS, 21/4/1934, p. 1).

48 Um município que forma com brilho entre os outros da Alta Araraquarense (A NOTÍCIA, 3 mar. 1933, p. 1).

49 Ponte sobre o Rio Borá (A FOLHA, 19 dez. 1941, p. 2).

50 Mirassol, o rico município da Alta Araraquarense (A NOTICIA, 6 mar. 1936, p. 1).

51 "Noroeste e Araraquarense pedem rodovia há 12 anos (JORNAL DE JALES, 24 dez. 1972, p. 1).

Célio José LOSNAK. Professor Assistente Doutor na Universidade Estadual Paulista Júlio de Mesquita Filho, Faculdade de Arquitetura, Artes e Comunicação de Bauru, Departamento de Ciências Humanas. Av. Eng. Luiz Edmundo Coube, s/no.

Vargem Limpa - Bauru, SP - Brasil 17033-360.

A pesquisa subsidiadora do texto foi financiada pela FAPESP.

Recebido em 7/7/2016

Aprovado em 21/2/2017 